\title{
HUBUNGAN PEMBAGIAN KERJA, KECERDASAN INDIVIDU TERHADAP PRESTASI KERJA PADA DINAS PENDIDIKAN DAN KEBUDAYAAN KECAMATAN KUALUH SELATAN KABUPATEN LABUHAN BATU UTARA
}

\author{
Raja Saul Marto Hendry \\ Manajemen, Fakultas Ekonomi \& Bisnis, Universitas Labuhanbatu \\ rajasaul365@gmail.com
}

\begin{abstract}
Abstrak
Penelitian ini bertujuan menganalisis hubungan pembagian kerja, kecerdasan individu dengan prestasi kerja pada Dinas Pendidikan Dan Kebudayaan Kecamatan Kualuh Selatan Kabupaten Labuhanbatu Utara. Metode pengumpulan data yang digunakan adalah observasi, wawancara, dan kuesioner. Data dianalisis dengan uji t dengan bantuan software SPSS 16.0 for windows. Dari hasil yang diperoleh dari pengolahan data : Terdapat korelasi yang positif dan cukup kuat antara pembagian kerja dengan prestasi kerja, dimana nilai korelasi yang diperoleh sebesar 0.478 , dan nilai $t$ hitung yang didapat lebih besar dari t tabel $(8.674>1.697)$. Terdapat korelasi yang positif dan sangat kuat antara kecerdasan individu dengan prestasi kerja. dimana nilai korelasi yang diperoleh sebesar 0.864 , dan nilai t hitung yang didapat lebih besar dari $\mathrm{t}$ tabel $(47.715>1.697)$. Serta terdapat korelasi yang positif dan cukup kuat antara pembagian kerja dengan kecerdasan individu, dimana nilai korelasi yang diperoleh sebesar 0.533 , dan nilai $t$ hitung yang didapat lebih besar dari $t$ tabel $(10.423>1.697)$. Sehingga dapat disimpulkan bahwa hubungan pembagian kerja, kecerdasan individu dengan prestasi kerja pada Dinas Pendidikan Dan Kebudayaan Kecamatan Kualuh Selatan Kabupaten Labuhanbatu Utara dalam penelitian ini saling berhubungan positif dan signifikan. Hal ini dibuktikan dari hasil korelasi pearson product moment serta uji $\mathrm{t}$ secara parsial untuk ketiga variabel (pembagian kerja, kecerdasan individu, prestasi kerja).
\end{abstract}

Kata Kunci : Pembagian Kerja, Kecerdasan Individu, Prestasi Kerja.

\section{PENDAHULUAN}

Salah satu tantangan yang dihadapi oleh manusia di masa depan adalah untuk menciptakan suatu organisasi yang memiliki sumber daya manusia yang berkualitas tinggi. Sumber daya yang baik ditujukan kepada peningkatan konstribusi yang dapat diperoleh dari pegawai terhadap organisasi kearah tercapainya tujuan organisasi. Pegawai merupakan kekayaan terpenting suatu institusi, karena tanpa keikutsertaan mereka, aktivitas organisasi tidak akan terjadi. Pegawai berperan aktif dalam menetapkan rencana sistem, proses dan tujuan yang ingin dicapai.

Penilaian prestasi kerja para pegawai merupakan bagian penting dari seluruh prose kekaryaan pegawai. Pentingnya penilaian prestasi kerja yang rasional dan diterapkan secara obyektif terlihat pada kepentingan pegawai maupun kepentingan organisasi.

Bagi para pegawai, penilaian tersebut berperan sebagai upan balik tentang hal seperti kemampuan, keletihan, kecerdasan, keletihan, kekurangan dan potensi yang bermanfaat untuk menentukan 
tujuan, jalur, rencana dan pengembangan kariernya.

Hasil penilaian prestasi kerja pegawai bagi organisasi sangat penting arti dan peranannya dalam pengambilan keputusan tentang berbagai hal, seperti identifikasi kebutuhan program pengenalan, penempatan, promosi, sistem imbalan dan berbagai aspek lain dari keseluruhan proses manajemen sumber daya manusia secara efektif.

Begitu juga halnya setiap organisasi, meningkatkan kinerja dan menghasilkan prestasi yang baik adalah keinginan dari unit pelaksanaan dalam pemerintahan. Untuk mencapai tujuan itu banyak faktor yang berhubungan dengan prestasi kerja yaitu motivasi, pembagian kerja, usaha, kemampuan, kecerdasan individu serta pengalaman, namun dalam penelitian ini hanya akan meneliti dua faktor yang berhubungan dengan pretasi kerja seorang pegawai yaitu pembagian kerja dan kecerdasan individu.

Pegawai yang punya kemampuan dan intelegensi yang tinggi tidak selalu menjamin prestasi kerja yang baik apabila moral dan kedisiplinannya rendah maka berakibat pada produktivitas yang rendah. Seorang pegawai dapat dikatakan mendukung pencapaian tujuan institusi jika memiliki keinginan untuk berprestasi. Oleh karena itulah, organisasi selalu menjaga kualitas pegawainya agar selalu baik dengan cara memberikan reward (penghargaan) kepada pegawai berprestasi dan sebaliknya, memberikan teguran dan punishment (hukuman) bagi pegawai yang performanya menurun atau kurang baik. Kualitas dan kuantitas pegawai dalam suatu organisasi harus sesuai dengan kebutuhan agar produktifitas menjadi efektif dan efisien.
Pembagian kerja yang sesuai dengan kemampuan yang dimiliki pegawai akan mempermudah dalam penyelesaian tugas. Pembagian kerja pegawai harus mempertimbangkan jenis dan jumlah tugas yang diberikan agar tidak ada pegawai yang merasa tugasnya lebih berat dibandingkan pegawai lain yang jabatannya sama.

\section{Landasan Teori}

\subsection{Prestasi Kerja}

Prestasi kerja yaitu suatu hasil kerja yang dicapai seseorang dalam melaksanakan tugas-tugas yang diberikan kepadanya yang didasarkan atas kecakapan, kesungguhan dan waktu prestasi kerja merupakan gabungan dari tiga faktor penting, yaitu kemampuan dan minat seorang pekerja, kemampuan dan penerimaan atas delegasi tugas serta peran dan tingkat motivasi seorang pekerja. Semakin tinggi ketiga faktor tersebut maka semakin besarlah prestasi kerja yang bersangkutan (Hasibuan, 2007 : 94).

Prestasi kerja adalah tingkat kemampuan seseorang dalam melaksanakan tugas-tugasnya yang dilihat dari tanggung jawab, kerja sama, kepemimpinan, kesetiaan, dan kedisiplinan kerja (Nitisemito, $2006: 160$ ).

Dengan demikian prestasi kerja merupakan ukuran suatu keberhasilan atau kemampuan maupun kesuksesan seseorang dalam menyelesaikan suatu pekerjaan yang dibebankan kepadanya melalui sikap orang tersebut dalam bekerja antara lain kerja sama, kejujuran, loyalitas, kepemimpinan, dan kedisiplinan kerja.

Unsur-unsur yang dinilai dalam prestasi kerja adalah kesetiaan, kedisiplinan, kejujuran, kreativitas, kerja sama, kepemimpinan, kepribadian, prakarsa, kecakapan, dan tanggung jawab (Hasibuan, 2007: 96). 
Malthis dan Jackson (2006 : 79) menyatakan, "prestasi kerja atau kinerja pada dasarnya adalah apa yang dilakukan atau tidak dilakukan karyawan. Prestasi kerja karyawan adalah yang mempengaruhi seberapa banyak mereka memberikan kontribusi kepada organisasi yang antara lain termasuk: (a) Kuantitas output, (b) Kualitas output, (c) Jangka waktu output, (d) Kehadiran di tempat kerja, dan (e) Sikap Kooperatif.

Prestasi kerja adalah perilaku yang ditampilkan oleh individu atau kelompok yang menurut Siagian (2008: 138) sebagai berikut : "Ditinjau dari segi keperilakuan, kepribadian seseorang sering menampakkan diri dalam beberbagai bentuk sikap, cara berfikir, dan cara bertindak berbagai hal yang memepengaruhi seseorang manusia organisasional yang tercermin dalam perilakunya yang pada gilirannya akan berpengaruh terhadap prestasi kerja.

Prestasi kerja menurut Handoko (2009:135) "Prestasi kerja adalah kegiatan yang paling penting untuk mewujudkan karir, karena hal ini mendasari semua kegiatan pengembangan karir lainnya dan prestasi kerja sebagai ukuran untuk memajukan karir karyawan menjadi lebih baik".

Dari pengertian diatas dapat disimpulkan bahwa prestasi kerja sebagai arti penting suatu pekerjaan, tingkat ketrampilan yang diperlukan, kemajuan dan tingkat penyelesaian suatu pekerjaan. Dan juga prestasai kerja mengandung pengertian produk atau jasa yang dihasilkan melalui serangkaian aktivitas serta kemampuan karyawan dalam mengerjakan tugasnya sesuai dengan standart kerja yang berlaku seperti mutu pekerjaan, volume pekerjaan, pengetahuan kerja, inisiatif dan sikap kerja serta sikap terhadap orang lain. Dan hal-hal yang mempengaruhi prestasi kerja dijelaskan secara terperinci sebagai berikut: sifat yang mengandung dorongan yang kuat untuk maju dan niat yang keras untuk memperoleh apa yang diinginkan.

\subsection{Pembagian Kerja}

Tugas merupakan suatu kewajiban dalam pekerjaan yang telah ditentukan dalam organisasi untuk melaksanakan pekerjaan yang telah ditetapkan dalam bidang masing-masing jabatan. Pekerjaan (job) terdiri dari sekelompok tugas yang harus dilaksanakan agar organisasi dapat mencapai tujuannya. Pembagian tugas terjadi karena setiap orang mempunyai kemampuan terbatas untuk melakukan segala pekerjaan.

Menurut Manullang (2006 : 190) pembagian tugas adalah penunjukan tugas atau kewajiban kepada orang lain untuk meringankan beban pekerjaan seseorang. Misalkan seorang manajer mendelegasikan sebagian pekerjaannya kepada bawahan yang dipercayainya dan ditunjuk untuk melaksanakan suatu pekerjaan yang tidak bisa dikerjakan sendiri oleh manajer tersebut. Pendelegasian bersifat dari atas ke bawah atau dari pimpinan ke bawahan.

Menurut Hasibuan (2007:33) "Pembagian kerja yaitu informasi tertulis yang menguraikan tugas dan tanggung jawab, kondisi pekerjaan, hubungan pekerjaan, dan aspek-aspek pekerjaan pada suatu jabatan tertentu dalam organisasi”.

Menurut Pophal (2008 : 8) "Pembagian kerja adalah rekaman tertulis mengenai tanggung jawab dari pekerjaan tertentu. Dokumen ini menunjukkan kualifikasi yang dibutuhkan untuk jabatan tersebut dan menguraikan bagaimana pekerjaan tersebut berhubungan dengan bagian lain dalam perusahaan". 
Menurut Rivai (2006 : 125) "Pembagian tugas adalah hasil analisis pekerjaan sebagai rangkaian kegiatan atau proses menghimpun dan mengolah informasi mngenai pekerjaan".

Menurut Wursanto (2009 : 230) pembagian tugas adalah hal yang sangat penting karena:

1. Pengetahuan, kemampuan dan keahlian sangat terbatas, sehingga tidak mungkin seseorang dapat melakukan semua jenis tugas sementara kegiatan dalam organisasi sangat kompleks.

2. Seseorang tidak mungkin mampu mengerjakan dua jenis tugas yang berbeda pada saat yang sama.

3. Tidak mungkin seseorang dapat berada pada dua tempat pada saat yang sama.

4. Setiap orang memiliki banyak kekurangan dan kelemahan, namun dalam hal-hal tertentu pasti memiliki kelebihan yang belum tentu dimiliki oleh orang lain.

Dalam menjalankan prinsip pembagian tugas ini, ada beberapa faktor yang perlu diperhatikan agar pembagian tugas menjadi efektif, yaitu:

1. Perincian tugas adalah sejumlah tugas yang telah ditetapkan dalam daftar tugas yang harus dilaksanakan oleh karyawan. Dengan adanya perincian tugas, jenis pekerjaan menjadi jelas dan dapat dipergunakan sebagai pedoman dalam melaksanankan tugas.

2. Jumlah tugas. Sebaiknya jumlah tugas yang diberikan kepada karyawan lebih dari satu untuk menghindari kejenuhan kerja. Akan tetapi tugas yang diberikan harus saling berhubungan dan disesuaikan dengan kemampuan karyawan itu sendiri.

3. Beban tugas. Beban tugas yang dibebankan ke masing-masing karyawan hendaknya sama atau seimbang dengan karyawan yang lainnya agar tidak terjadi ketimpangan beban tugas.

4. Penggolongan tugas. Penggolongan tugas dapat dibagi menjadi dua macam, yaitu tugas utama rutin yang memang sebagai tugas harian atau tugas yang memang dikerjakan setiap hari dan tugas utama periodik yang hanya dilakukan pada saat tertentu apabila dibutuhkan.

Pembagian kerja dilakukan agar setiap karyawan menjadi lebih ahli dalam menangani tugasnya, karena tugas yang telah dibagi merupakan bidang tertentu sesuai dengan kemampuannya. Pembagian tugas yang baik merupakan kunci bagi seluruh organisasi terutama dalam memberikan jaminan terhadap kestabilan, kelancaran dan efisiensi kerja. Sebaliknya jika pembagian tugas itu dilakukan dengan ceroboh, artinya tidak menyesuaikan kemampuan seseorang dengan bidang pekerjaannya, maka akan bepengaruh tidak baik bahkan dapat menimbulkan kegagalan dalam pelaksanaan pekerjaannya.

\subsection{Kecerdasan Individu \\ 1. Kecerdasan Intelektual (IQ)}

Kecerdasan dalam arti umum adalah suatu kemampuan umum yang membedakan kualitas orang yang satu dengan orang yang lain. Kecerdasan intelektual lazim disebut dengan inteligensi. Istilah ini dipopulerkan kembali pertama kali oleh Francis Galton, seorang ilmuwan dan ahli matematika yang terkemuka dari Inggris. Inteligensi adalah kemampuan kognitif yang dimiliki organisme untuk menyesuaikan diri secara efektif pada lingkungan yang kompleks dan selalu berubah serta dipengaruhi oleh faktor genetik (Joseph, dalam Golomen 2007 : 820).

Raven memberikan pengertian yang lain. Ia mendefinisikan inteligensi sebagai 
kapasitas umum individu yang nampak dalam kemampuan individu untuk menghadapi tuntutan kehidupan secara rasional (Suryabrata, 1998:66 dalam Fabiola 2006: 15).

Intelligensi lebih difokuskan kepada kemampuannya dalam berpikir. Wechslerseorang ilmuwan dari Amerika adalah orang yang membuat test inteligensi WAIS dan WISC yang banyak digunakan diseluruh dunia. Ia mengemukakan bahwa inteligensi adalah kemampuan global yang dimiliki oleh individu agar bisa bertindak secara terarah dan berpikir secara bermakna serta bisa berinteraksi dengan lingkungan secara efisien (Anastasi dan Urbina, 2006 : 220).

Spearman mengelompokan inteligensi ke dalam dua kategori. Kategori yang pertama adalah $g$ factor atau biasa disebut dengan kemampuan kognitif yang dimiliki individu secara umum, misalnya kemampuan mengingat dan berpikir. Kategori yang kedua disebut dengan $s$ factor yaitu merupakan kemampuan khusus yang dimiliki individu (Eysenck, 2006 : 13).

$\mathrm{G}$ faktor lebih merupakan potensi dasar yang dimiliki oleh setiap orang unuk belajar dan beradaptasi. Intelligensi ini dipengaruhi oleh faktor bawaan. Faktor s merupakan intelligensi yang dipengaruhi oleh lingkungan sehingga faktor s yang dimiliki oleh orang yang satu akan berbeda dengan orang yang lain. Setiap faktor s pasti mengandung faktor $\mathrm{g}$. Istilah inteligensi digunakan dengan pengertian yang luas dan bervariasi, tidak hanya oleh masyarakat umum tetapi juga oleh anggota-anggota berbagai disiplin ilmu (Anastasi, 2006 : 219).

Anastasi (2006 : 220) mengatakan bahwa inteligensi bukanlah kemampuan tunggal dan seragam tetapi merupakan komposit dari berbagai fungsi. Istilah ini umumnya digunakan untuk mencakup gabungan kemampuan-kemampuan yang diperlukan untuk bertahan dan maju dalam budaya tertentu. Kemampuan intelektual ini dapat diukur dengan suatu alat tes yang biasa disebut IQ (Intellegence Quotient). IQ adalah ekspresi dari tingkat kemampuan individu pada saat tertentu, dalam hubungan dengan norma usia yang ada.

Eysenck (2006 : 26) menyebutkan bahwa ada berbagai macampengukuran inteligensi dan setiap tes IQ yang digunakan akan disesuaikan dengan tujuan dan kebutuhan dari penggunaan tes IQ tersebut.

\section{Kecerdasan Emosional (EQ)}

Orang yang pertama kali mengungkapkan adanya kecerdasan lain selain akademik yang dapat mempengaruhi keberhasilan seseorang adalah Gardner. Kecerdasan lain itu disebut dengan emotional intelligence atau kecerdasan emosi (Goleman, 2007 : 51).

Kecerdasan emosi merupakan kemampuan untuk menggunakan emosi secara efektif dalam mengelola diri sendiri dan mempengaruhi hubungan dengan orang lain secara positif. Menurut Salovey dan Mayer, (2008 : 11) kecerdasan emosi adalah kemampuan untuk merasakan emosi, menerima dan membangun emosi dengan baik, memahami emosi dan pengetahuan emosional sehingga dapat meningkatkan perkembangan emosi dan intelektual.

Salovey (2008:12) juga memberikan definisi dasar tentang kecerdasan emosi dalam lima wilayah utama yaitu, kemampuan mengenali emosi diri, mengelola emosi diri, memotivasi diri sendiri, mengenali emosi orang kain, dan kemampuan membina hubungan dengan orang lain. 
Seorang ahli kecerdasan emosi, Goleman (2007 : 13) mengatakan bahwa yang dimaksud dengan kecerdasan emosi di dalamnya termasuk kemampuan mengontrol diri, memacu, tetap tekun, serta dapat memotivasi diri sendiri. Kecakapan tersebut mencakup pengelolaan bentuk emosi baik yang positif maupun negatif.

Purba (dalam Fabiola, 2006 : 64) berpendapat bahwa kecerdasan emosi adalah kemampuan di bidang emosi yaitu kesanggupan menghadapi frustasi, kemampuan mengendalikan emosi, semamgat optimisme, dan kemampuan menjalin hubungan dengan orang lain atau empati. Hal tersebut seperti yang dikemukakan Patton (2008 : 3) bahwa penggunaan emosi yang efektif akan dapat mencapai tujuan dalam membangun hubungan yang produktif dan meraih keberhasilan kerja.

\subsection{Kecerdasan Spritual (SQ)}

Pada masa kini orang mulai mengenal istilah kecerdasan lain disamping kedua kecerdasan diatas, yaitu kecerdasan spiritual. Zohar dan Marshal (2007 : 37) mendefinisikan kecerdasan spiritual sebagai rasa moral, kemampuan menyesuaikan aturan yang kaku dibarengi dengan pemahaman dan cinta serta kemampuan setara untuk melihat kapan cinta dan pemahaman sampai pada batasannya, juga memungkinkan kita bergulat dengan ihwal baik dan jahat, membayangkan yang belum terjadi serta mengangkat kita dari kerendahan. Kecerdasan tersebut menempatkan perilaku dan hidup kita dalam konteks makna yang lebih luas dan kaya, kecerdasan untuk menilai bahwa tindakan atau jalan hidup sesorang lebih bernilai dan bermakna.

Sedangkan Eckersley (2006 : 5) memberikan pengertian yang lain mengenai kecerdasan spiritual. Kecerdasan spiritual didefinisikan sebagai perasaan intuisi yang dalam terhadap keterhubungan dengan dunia luas didalam hidup kita.

Konsep mengenai kecerdasan spiritual dalam hubungannya dengan dunia kerja, menurut Ashmos dan Duchon (2008:6) memiliki tiga komponen yaitu kecerdasaan spiritual sebagai nilai kehidupan dari dalam diri, sebagai kerja yang memiliki arti dan komunitas.

Mccormick (1994:20) dan Mitroff and Denton (1999:111), dalam penelitiannya membedakan kecerdasan spriritual dengan religiusitas di dalam lingkungan kerja. Religiusitas lebih ditujukan pada hubungannya dengan Tuhan sedangkan kecerdasan spiritual lebih terfokus pada suatu hubungan yang dalam dan terikat antara manusia dengan sekitarnya secara luas.

Berman (2005 : 98) mengungkapkan bahwa kecerdasan spiritual (SQ) dapat memfasilitasi dialog antara pikiran dan emosi, antara jiwa dan tubuh. Dia juga mengatakan bahwa kecerdasan spiritual juga dapat membantu sesorang untuk dapat melakukan transedensi diri. Pengertian lain mengenai kecerdasan spiritual adalah kemampuan untuk memberi makna ibadah terhadap setiap perilaku dan kegiatan melalui langkah-langkah dan pemikiran yang bersifat fitrah, menuju manusia yang seutuhnya dan memiliki pola pemikiran integralistik serta berprinsip hanya karena Allah (Agustian, 2006 : 57).

\subsection{Kerangka Konseptual}

Kerangka konseptual dapat dilihat pada gambar berikut : 


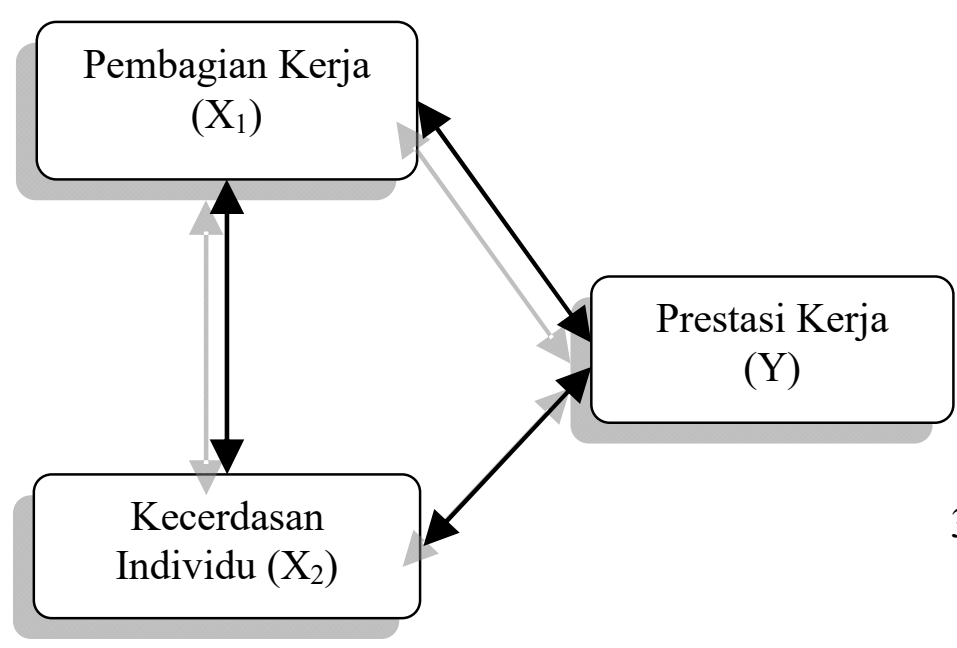

Gambar 1. Kerangka Konseptual

\section{METODE PENELITIAN}

A. Analisis Koefisien Korelasi Product Moment (Pearson)

Menurut Sugiyono (2010 : 248)

Korelasi merupakan salah satu metode penelitian secara kuantitatif asosiasi ataupun relasi satu variabel interval dengan variabel interval lainnya. Pengujian ini dilakukan untuk mengetahui apakah semua independen berhubungan terhadap variabel dependen. Langkah-langkah sebagai berikut :

a. Menentukan Hipotesa nihil dan hipotesa alternatif

1. Ho1 $: \mathrm{p}=0$ Tidak ada hubungan antara pembagian kerja dengan prestasi kerja pegawai pada Dinas Pendidikan dan Kebudayaan Kecamatan Kualuh Selatan Kabupaten Labuhanbatu Utara.

Hal $: p \neq 0 \quad$ Ada hubungan antara pembagian kerja dengan prestasi kerja pegawai pada Dinas Pendidikan dan Kebudayaan Kecamatan Kualuh Selatan Kabupaten Labuhanbatu Utara.

2. Ho2 $: \mathrm{p}=0$ Tidak ada hubungan antara kecerdasan individu dengan prestasi kerja pegawai pada Dinas Pendidikan dan Kebudayaan Kecamatan Kualuh Selatan Kabupaten Labuhanbatu Utara.

$\mathrm{Ha} 2: \mathrm{p} \neq 0$ Ada hubungan antara kecerdasan individu dengan prestasi kerja pegawai pada Dinas Pendidikan dan Kebudayaan Kecamatan Kualuh Selatan Kabupaten Labuhanbatu Utara.

3. Ho3: $\mathrm{p}=0$ Tidak ada hubungan antara pembagian kerja dengan kecerdasan individu pegawai pada Dinas Pendidikan dan Kebudayaan Kecamatan Kualuh Selatan Kabupaten Labuhanbatu Utara.

$\mathrm{Ha} 3: \mathrm{p} \neq 0 \quad$ Ada hubungan antara pembagian kerja dengan kecerdasan individu pegawai Dinas Pendidikan dan Kebudayaan Kecamatan Kualuh Selatan Kabupaten Labuhanbatu Utara.

b. Level of Significant $=5 \%$

c. Pengujian besar korelasi

$$
\begin{aligned}
& \text { Rumus } \\
& r_{X Y}=\frac{n\left(\sum X Y\right)-\left(\sum X\right)\left(\sum Y\right)}{\sqrt{\left(n \cdot \sum X^{2}-\left(\sum X^{2}\right)\right)-\left(n \cdot \sum Y^{2}-\left(\sum Y^{2}\right)\right)}}
\end{aligned}
$$

Dimana $\quad \mathrm{r}_{\mathrm{xy}}=$ Koefisien korelasi antara $\mathrm{x}$ dan $\mathrm{y}$

$$
\begin{aligned}
& \mathrm{n}=\text { Jumlah responden } \\
& \mathrm{X}=\begin{array}{c}
\text { Variabel yang } \\
\text { mempengaruhi yaitu } \\
\text { pembagian kerja dan }
\end{array} \\
& \mathrm{kecerdasan} \text { individu } \\
& \mathrm{Y}=\text { Variabel yang } \\
& \text { dipengaruhi yaitu efektivitas } \\
& \text { kerja pegawai }
\end{aligned}
$$

d. Korelasi diukur dengan suatu koefisien (r) yang mengindikasikan seberapa banyak relasi antar dua variabel. Daerah nilai yang mungkin adalah +1.00 sampai 
-1.00. Dengan +1.00 menyatakan hubungan yang sangat erat, sedangkan 1.00 menyatakan hubungan negatif yang erat. Panduan untuk nilai korelasi tersebut:

e. Nilai koefisien (r) yang diperoleh dari pengujian korelasi Pearson Product Moment digunakan untuk mencari nilai $t$ hitung. Adapaun rumus t hitung adalah sebagai berikut:

$$
\text { thitung }=r \sqrt{\frac{n-2}{1-r^{2}}}
$$

Dasar pengambilan keputusannya adalah dengan menggunakan perbandingan nilai thitung dengan $t$ tabel, yaitu:

a. Apabila nilai $\mathrm{t}$ hitung $<\mathrm{t}$ tabel, berarti tidak terdapat hubungan yang signifikan antara variabel bebas dengan variabel terikat.

b. Apabila nilai $t$ hitung $>\mathrm{t}$ tabel, maka Ho ditolak dan Ha diterima. berarti tidak terdapat hubungan yang signifikan antara variabel bebas dengan variabel terikat.

\section{HASIL PENELITIAN DAN PEMBAHASAN}

A. Hasil Penelitian

1. Hasil Uji Korelasi antara Pembagian Kerja Dengan Prestasi Kerja Hipotesis:

Ho1 $: \mathrm{p}=0$ Tidak ada hubungan antara pembagian kerja dengan prestasi kerja pegawai pada Dinas Pendidikan dan Kebudayaan Kecamatan Kualuh Selatan Kabupaten Labuhanbatu Utara.

Ha1 $: p \neq 0$ Ada hubungan antara pembagian kerja dengan prestasi kerja pegawai pada Dinas Pendidikan dan Kebudayaan Kecamatan Kualuh Selatan Kabupaten Labuhanbatu Utara.
Berdasarkan tabel di atas dapat dilihat bahwa koefisien korelasi (r) pembagian kerja dengan Prestasi Kerja adalah 0.478 . Artinya terdapat hubungan yang positif dan cukup kuat antara Pembagian Kerja dengan Prestasi Kerja. Nilai r yang didapat dari hasil penelitian dengan meggunakan SPSS 16.0 for Windows tersebut dapat digunakan untuk mencari nilai t hitung sebagai berikut:

$$
\begin{aligned}
& \text { thitung }=r \sqrt{\frac{n-2}{1-r^{2}}} \\
& \text { thitung }=0.478 \sqrt{\frac{30-2}{1-0.478^{2}}} \\
& \text { thitung }=8.674
\end{aligned}
$$

Berdasarkan hasil $t$ hitung yang telah didapat, maka dapat dilihat bahwa nilai $t$ hitung lebih besar dari $t$ tabel (8.674 > 1.697), sehingga dapat diambil kesimpulan bahwa hipotesis Ha diterima dan $\mathrm{H}_{0}$ ditolak. Berarti bahwa pembagian kerja dengan prestasi kerja memiliki korelasi yang signifikan, dimana tingkat korelasi kedua variabel pembagian kerja dengan prestasi kerja yaitu korelasi yang cukup kuat. Artinya Pembagian Kerja berhubungan secara signifikan dengan Prestasi Kerja dimana apabila Pembagian Kerja dilakukan dengan baik, maka Prestasi Kerja juga akan semakin baik dan sebaliknya, apabila Pembagian Kerja tidak dilakukan dengan baik maka Prestasi Kerja juga tidak akan baik.

2. Hasil Uji Korelasi antara Kecerdasan Individu Dengan Prestasi Kerja Hipotesis:

Ho1 $: \mathrm{p}=0$ Tidak ada hubungan antara kecerdasan individu dengan prestasi kerja pegawai pada Dinas Pendidikan dan Kebudayaan Kecamatan 


\section{Kualuh Selatan Kabupaten Labuhanbatu Utara. \\ Ha1 $: p \neq 0$ Ada hubungan antara kecerdasan individu dengan prestasi kerja pegawai pada Dinas Pendidikan dan Kebudayaan Kecamatan Kualuh Selatan Kabupaten Labuhanbatu Utara.}

Berdasarkan tabel di atas dapat dilihat bahwa koefisien korelasi (r) Kecerdasan Individu dengan Prestasi Kerja adalah 0.864 . Artinya terdapat hubungan yang positif dan sangat kuat antara Kecerdasan Individu dengan Prestasi Kerja. Nilai $r$ yang didapat dari hasil penelitian dengan meggunakan SPSS 16.0 for Windows tersebut dapat digunakan untuk mencari nilai t hitung sebagai berikut:

$$
\begin{aligned}
& \text { thitung }=r \sqrt{\frac{n-2}{1-r^{2}}} \\
& \text { thitung }=0.864 \sqrt{\frac{30-2}{1-0.864^{2}}} \\
& \text { thitung }=47.715
\end{aligned}
$$

Berdasarkan hasil $\mathrm{t}$ hitung yang telah didapat, maka dapat dilihat bahwa nilai $\mathrm{t}$ hitung lebih besar dari t tabel (47.715 > 1.697), sehingga dapat diambil kesimpulan bahwa hipotesis Ha diterima dan $\mathrm{H}_{0}$ ditolak. Berarti bahwa kecerdasan individu dengan prestasi kerja memiliki korelasi yang signifikan, dimana tingkat korelasi kedua variabel kecerdasan individu dengan prestasi kerja yaitu korelasi yang sangat kuat. Artinya Pembagian Kerja berhubungan secara signifikan dengan Prestasi Kerja dimana apabila kecerdasan individu yang dimiliki pegawai tinggi, maka Prestasi Kerja yang dimiliki juga tinggi dan sebaliknya, apabila kecerdasan individu yang dimiliki pegawai rendah, maka Prestasi Kerja yang dimiliki juga rendah.

3. Hasil Uji Korelasi antara Pembagian Kerja Dengan Kecerdasan Individu Hipotesis:

Ho1 $: \mathrm{p}=0$ Tidak ada hubungan antara pembagian kerja dengan kecerdasan individu pegawai pada Dinas Pendidikan dan Kebudayaan Kecamatan Kualuh Selatan Kabupaten Labuhanbatu Utara.

Ha1 $: p \neq 0$ Ada hubungan antara pembagian kerja dengan kecerdasan individu pegawai pada Dinas Pendidikan dan Kebudayaan Kecamatan Kualuh Selatan Kabupaten Labuhanbatu Utara.

Berdasarkan tabel di atas dapat dilihat bahwa koefisien korelasi (r) Pembagian Kerja dengan Kecerdasan Individu adalah 0.533 . Artinya terdapat hubungan yang positif dan cukup kuat antara Pembagian Kerja dengan Kecerdasan Individu. Nilai $r$ yang didapat dari hasil penelitian dengan meggunakan SPSS 16.0 for Windows tersebut dapat digunakan untuk mencari nilai t hitung sebagai berikut:

$$
\begin{aligned}
& \text { thitung }=r \sqrt{\frac{n-2}{1-r^{2}}} \\
& \text { thitung }=0.533 \sqrt{\frac{30-2}{1-0.533^{2}}} \\
& \text { thitung }=10.423
\end{aligned}
$$

Berdasarkan hasil t hitung yang telah didapat, maka dapat dilihat bahwa nilai $t$ hitung lebih besar dari t tabel (10.423 > 1.697), sehingga dapat diambil 
kesimpulan bahwa hipotesis Ha diterima dan $\mathrm{H}_{0}$ ditolak. Berarti bahwa Pembagian Kerja dengan Kecerdasan Individu memiliki korelasi yang signifikan, dimana tingkat korelasi kedua variabel Pembagian Kerja dengan Kecerdasan Individu yaitu korelasi yang cukup kuat. Artinya Pembagian Kerja berhubungan secara signifikan dengan Kecerdasan Individu dimana apabila Kecerdasan Individu tinggi maka pembagian kerja yang diterima akan semakin banyak. Begitu juga sebaliknya makin rendah kecerdasan individu maka pembagian kerja yang diberikan kepadanya semakin sedikit.

\section{B. Pembahasan}

1. Hubungan Pembagian Kerja Dengan Prestasi Kerja

Pada penelitian ini diperoleh nilai korelasi antara pembagian kerja dengan prestasi kerja sebesar 0.478 , dan dimana nilai t hitung yang didapat lebih besar dari $t$ tabel $(8.674>1.697)$ sehingga dapat diambil kesimpulan bahwa ada korelasi yang positif dan cukup kuat antara pembagian kerja dengan prestasi kerja. Artinya apabila Pembagian Kerja dilakukan dengan baik, maka Prestasi Kerja juga akan semakin baik dan sebaliknya, apabila Pembagian Kerja tidak dilakukan dengan baik maka Prestasi Kerja juga tidak akan baik.

Hasil penelitian ini mengacu dari penelitian yang dilakukan oleh Gresmita Yulia Situmorang dan Prihatin Lumbanraja (2012) melakukan penelitian tentang hubungan pembagian kerja dan wewenang perusahaan dengan prestasi kerja di Kantor Pertanahan Kota Medan. Diperoleh hasil penelitian berdasarkan uji korelasi pearson yaitu terdapat hubungan yang positif dan kuat antara Pembagian Tugas dengan Prestasi Kerja. Dan penelitian yang dilakukan Sofyan Sauri Rakhman (2010) tentang pengaruh pembagian kerja, kepemimpinan, pemberian penghargaan dan penilaian kinerja terhadap produktivitas kerja karyawan BUMIDA syariah. Diperoleh hasil penelitian variabel pembagian kerja berpengaruh positif dan signifikan terhadap produktivitas kerja karyawan. Sehingga dapat disimpulkan bahwa penelitian yang telah penulis lakukan sejalan dengan penelitian terdahulu.

\subsubsection{Hubungan Kecerdasan Individu Dengan Prestasi Kerja}

Pada penelitian ini juga diperoleh nilai korelasi antara kecerdasan individu dengan prestasi kerja sebesar 0.864, dan dimana nilai $t$ hitung yang didapat lebih besar dari $t$ tabel $(47.715>1.697)$ sehingga dapat diambil kesimpulan bahwa ada korelasi yang positif dan sangat kuat antara kecerdasan individu dengan prestasi kerja. Artinya apabila kecerdasan individu yang dimiliki pegawai tinggi, maka prestasi kerja yang dimiliki juga tinggi dan sebaliknya, dan apabila kecerdasan individu yang dimiliki pegawai rendah, maka Prestasi Kerja yang dimiliki juga rendah.

Hasil penelitian ini mengacu dari penelitian yang dilakukan oleh Pingkan Moniaga (2012) melakukan penelitian tentang analisis pengaruh kecerdasan emosional, kecerdasan spiritual, dan kecerdasan intelektual terhadap kinerja karyawan (Studi Kasus Pada PT. Bank Sulut Kantor Pusat). Diperoleh hasil penelitian bahwa kecerdasan emosional, kecerdasan spiritual, dan kecerdasan intelektual berpengaruh terhadap kinerja karyawan. Sehingga dapat disimpulkan bahwa penelitian yang telah penulis lakukan sejalan dengan penelitian terdahulu. 
3 Hubungan Pembagian Kerja Dengan Kecerdasan Individu

Pada penelitian ini juga diperoleh nilai korelasi antara pembagian kerja dengan kecerdasan individu sebesar 0.533, dan dimana nilai $\mathrm{t}$ hitung yang didapat lebih besar dari $t$ tabel $(10.423>1.697)$ sehingga dapat diambil kesimpulan bahwa ada korelasi yang positif dan cukup kuat antara pembagian kerja dengan kecerdasan individu. Artinya apabila tingkat Kecerdasan Individu seorang pegawai tersebut tinggi maka pembagian kerja yang diterimanya akan semakin banyak. Begitu juga sebaliknya makin rendah tigkat kecerdasan individu seorang pegawai maka pembagian kerja yang diberikan kepadanya semakin sedikit.

Hasil penelitian ini mengacu dari penelitian yang dilakukan oleh Tri Pambudi Sampurno (2008) melakukan penelitian tentang Pembagian kerja antara laki-lakidan perempuan di Dusun Sambirejo Desa Seloharjo Kecamatan Pundong Kabupaten Bantul. Diperoleh hasil penelitian bahwa jenis kelamin berpengaruh terhadap pembagian kerja, Usia juga berpengaruh terhadap pembagian kerja dan kecerdasan juga mempengaruhi pembagian kerja. . Sehingga dapat disimpulkan bahwa penelitian yang telah penulis lakukan sejalan dengan penelitian terdahulu.

\section{KESIMPULAN DAN SARAN}

\subsection{Kesimpulan}

Berdasarkan hasil penelitian hubungan pembagian kerja, kecerdasan individu dengan prestasi kerja pada Dinas Pendidikan Dan Kebudayaan Kecamatan Kualuh Selatan Kabupaten Labuhanbatu Utara yang telah dilakukan, maka dapat disimpulkan bahwa:
1. Variabel Pembagian Kerja berhubungan positif dan signifikan terhadap Prestasi Kerja pada Dinas Pendidikan Dan Kebudayaan Kecamatan Kualuh Selatan Kabupaten Labuhanbatu Utara. Dimana koefisien korelasi (r) pembagian kerja dengan Prestasi Kerja adalah 0.478 . Artinya kedua variabel memiliki tingkat hubungan yang cukup kuat.

2. Variabel Kecerdasan Individu berhubungan positif dan sangat kuat terhadap Prestasi Kerja pada Dinas Pendidikan Dan Kebudayaan Kecamatan Kualuh Selatan Kabupaten Labuhanbatu Utara. Dimana koefisien korelasi (r) Kecerdasan Individu dengan Prestasi Kerja adalah 0.864. Artinya kedua variabel memiliki tingkat hubungan yang sangat kuat.

3. Variabel Pembagian Kerja berhubungan positif dan cukup kuat terhadap Kecerdasan Individu pada Dinas Pendidikan Dan Kebudayaan Kecamatan Kualuh Selatan Kabupaten Labuhanbatu Utara. Dimana koefisien korelasi (r) Kecerdasan Individu dengan Prestasi Kerja adalah 0.533 . Artinya kedua variabel memiliki tingkat hubungan yang sangat kuat.

\subsection{Saran}

Dari hasil kesimpulan diatas peneliti dapat memberikan saran kepada Peneliti Selanjutnya dan Dinas Pendidikan Dan Kebudayaan Kecamatan Kualuh Selatan Kabupaten Labuhanbatu Utara sebagai berikut:

- Bagi Peneliti selanjutnya.

Disarankan agar peneliti selanjutnya menggunakan variabel-variabel lain 
selain Pembagian Kerja dan Kecerdasan Individu yang mempunyai hubungan dengan Prestasi Kerja. Dikarenakan Pada penelitian ini hanya Kecerdasan Individu dengan Prestasi Kerja yang mempunyai hubungan yang sangat kuat. Sedangkan hubungan Pembagian Kerja dengan Prestasi Kerja dan hubungan Pembagian Kerja dan Kecerdasan Individu hanya mempunyai hubungan cukup kuat.

- Bagi Dinas Pendidikan Dan Kebudayaan Kecamatan Kualuh Selatan Kabupaten Labuhanbatu Utara.

Pihak Dinas Pendidikan dan Kebudayaan Kecamatan Kualuh Selatan Kabupaten Labuhanbatu Utara hendaknya lebih memperhatikan pembagian kerja yang diberikan kepada pegawainya, diharapkan pembagian kerja lebih didasarkan kecerdasan individu masing-masing pegawai. Diharapkan dari pembagian kerja berdasarkan kecerdasan individu tersebut diharapkan akan meningkatnya prestasi kerja pegawai yang ada di Dinas Pendidikan Dan Kebudayaan Kecamatan Kualuh Selatan Kabupaten Labuhanbatu Utara.

\section{DAFTAR PUSTAKA}

[1] Anastasi, A dan Urbina, S. 2006. Tes Psikologi (Physiological Testing) Edisi ke 7. Jakarta : PT. Prehanlindo.

[2] Arikunto, Suharsimi. 2007. Prosedur Penelitian, Suatu Pendekatan Praktek. Jakarta : Penerbit Rineka Cipta.

[3] Eysenck, HJ, and Kamin, L. 2006. Intelligence : The Batle For The Mind, London and Sydney : Pan Book. Edisi Terjemahan. . Jakarta : Gramedia Pustaka Utama
[4] Golomen, D. 2007. Kecerdasan Emosi :Mengapa Emotional Intelligence Leih Tinggi Daripada IQ. Ahli Bahasa : T. Hermay. Jakarta : Gramedia Pustaka Utama

[5] Handoko, T. Hani. 2009. Manajemen Personalia dan Sumberdaya Manusia. Yogyakarta: BPFE.

[6] Hariandja, Marihot Tua Efendi. 2009. Manajemen Sumber Daya Manusia. Jakarta: Grasindo.

[7] Hasibuan, Melayu SP. 2007. Manajemen Sumber Daya Manusia. Jakarta : Penerbit Bumi Aksara.

[8] Imam, Ghozali. 2006. Aplikasi Analisis Multivariate dengan Program SPSS. Semarang : Badan Penerbit Universitas Diponegoro.

[9] Rivai, Veithzal. 2006. Manajemen Sumber Daya Manusia untuk Perusahaan. Jakarta : Rajagrafindo Persada.

[10] Siagian, Sondang. P. 2008. Kiat Meningkatkan Produktivitas Kerja. Jakarta : PT Rineka Cipta.

[11] Situmorang, Gresmita Yulia dan Prihatin Lumbanraja. 2012. Hubungan Pembagian Kerja Dan Wewenang Perusahaan Dengan Prestasi Kerja Di Kantor Pertanahan Kota Medan. Jurnal Akademik Universitas Sumatera Utara.

[12] Sugiyono. 2010. Metode Penelitian Bisnis. Bandung : Penerbit CV. Mandan Maju

[13] Trihandini, R.A Fabiola Meirnayati. 2006. Analisis Pengaruh Kecerdasan Intelektual, Kecerdasan Emosi dan Kecerdasan Spiritual terhadap Kinerja Karyawan (Studi Kasus di Hotel Horison Semarang). Tesis Universitas Diponegoro, Semarang. 